\title{
FAKTOR-FAKTOR YANG BERHUBUNGAN DENGAN PENGETAHUAN IBU NIFAS TENTANG TANDA BAHAYA NIFAS DI WILAYAH PUSKESMAS PANGKAH KABUPATEN TEGAL
}

\author{
Siti Erniyati Berkah Pamuji ${ }^{1}$, Yuni Fitriani ${ }^{2}$, Masturoh $^{3}$ \\ ${ }_{1,2,3}$ Prodi DIII Kebidanan STIKes Bhakti Mandala Husada Slawi \\ Email/cp: erniyatis@yahoo.co.id/081326877987
}

\begin{abstract}
Masa nifas adalah masa setelah melahirkan selama 6 minggu atau 40 hari. Proses ini dimulai setelah selesainya persalinan dan berakhir setelah alat-alat reproduksi kembali seperti keadaan sebelum hamil/tidak hamil. Selama waktu tersebut pada seorang ibu nifas seringkali terjadi masalah tanda-tanda bahaya masa nifas diantaranya perdarahan post partum, lochea yang berbau busuk, subinvolusi uterus, nyeri pada perut dan pelvis, pusing yang berlebihan, suhu tubuh ibu $>38^{\circ} \mathrm{C}$, mastitis, baby blues dan depresi postpartum. Data Dinas Kesehatan Kabupaten Tegal, angka kematian ibu di Kabupaten Tegal pada tahun 2015 sebanyak 33 orang, 5 orang $(15,15 \%)$ meninggal pada masa hamil, 10 orang $(30,30 \%)$ meninggal pada saat persalinan dan 18 orang $(54,55 \%)$ meninggal pada masa nifas. Tujuan penelitian ini adalah untuk mengetahui faktor-faktor yang berhubungan dengan pengetahuan ibu nifas tentang tanda bahaya nifas di Puskesmas Pangkah Kabupaten Tegal.

Hasil penelitian menunjukkan bahwa ada hubungan antara faktor umur, pendidikan, pengalaman melahiran dan keterpaparan informasi terhadap pengetahuan ibu nifas tentang tanda bahaya nifas. Faktor pendidikan memiliki hubungan yang erat dengan pengetahuan ibu nifas, sedangkan faktor pengalaman melahirkan, keterpaparan informasi memiliki hubungan yang sedang dengan pengetahuan ibu nifas. Faktor pekerjaan hampir tidak berhubungan dengan pengetahuan ibu nifas. Diharapkan ibu nifas meningkatkan pengetahuan dalam perawatan masa nifas, meningkatkan kemampuan dalam melakukan deteksi dini tanda bahaya nifas dan faktor resikonya serta segera melakukan pemeriksaan ke tenaga kesehatan bila menemukan tanda bahaya sehingga tidak terlambat dalam penatalaksanaannya.
\end{abstract}

Kata kunci : Tanda Bahaya Nifas, Pengetahuan

\section{FACTORS CORRELATED WITH POSTPARTUM MOTHER KNOWLEDGE OF DANGER SIGNS IN POSTPARTUM IN THE PANGKAH PUBLIC HEALTH CENTER OF TEGAL CITY}

Postpartum period is the period after giving birth for 6 weeks or 40 days. This process begins after the completion of labor and ends after the reproductive organs return to their pre-pregnancy / nonpregnant state. During this time in a postpartum mother there is often the problem of danger signs during puerperium including post partum bleeding, foul-smelling lochea, subinvolution of the uterus, abdominal and pelvic pain, excessive dizziness, maternal body temperature $>38^{\circ} \mathrm{C}$, mastitis, baby blues and postpartum depression. Data from the Tegal District Health Office, the maternal mortality rate in Tegal Regency in 2015 was 33 people, 5 people (15.15\%) died during pregnancy, 10 people (30.30\%) died during childbirth and 18 people $(54,55 \%)$ died during the puerperium. The purpose of this study was to determine the factors associated with postpartum mothers' knowledge of puerperal danger signs at Pangkah Health Center in Tegal Regency.

The results showed that there was a relationship between age, education, birth experience and information exposure to postpartum mothers' knowledge of puerperal danger signs. Educational factors have a close relationship with the knowledge of postpartum mothers, while the factors of childbirth experience, information exposure have a moderate relationship with the knowledge of postpartum mothers. Job factors are almost not related to the knowledge of postpartum mothers. It is hoped that postpartum mothers will increase their knowledge in postpartum care, improve their ability to detect early puerperal danger signs and risk factors and immediately conduct an examination of health workers when they find danger signs so that they are not late in their management.

Key words: Danger Signs of Postpartum Mother, Knowledge 


\section{PENDAHULUAN}

Masa nifas adalah masa setelah melahirkan selama 6 minggu atau 40 hari menurut hitungan awam. Proses ini dimulai setelah selesainya persalinan dan berakhir setelah alat-alat reproduksi kembali seperti keadaan sebelum hamil/tidak hamil sebagai akibat adanya perubahan fisiologi daan psikologi karena proses persalinan ${ }^{2}$. Dimana selama waktu tersebut pada seorang ibu nifas seringkali terjadi masalah tanda-tanda bahaya masa nifas di antaranya perdarahan post partum, lochea yang berbau busuk, subinvolusi uterus, nyeri pada perut dan pelvis, pusing yang berlebihan, suhu tubuh ibu $>38^{\circ} \mathrm{C}$, mastitis, baby blues dan depresi postpartum. Masa nifas merupakan masa yang kritis bagi ibu yang sehabis melahirkan. Diperkirakan bahwa 60\% kematian ibu terjadi setelah persalinan dan $50 \%$ diantaranya terjadi dalam selang waktu 24 jam pertama $^{15,16}$.

Hasil Survei Demografi dan Kesehatan Indonesia (SDKI) pada tahun 2012 menyebutkan, sepanjang periode 2007-2012 kasus kematian ibu melonjak cukup tajam. Diketahui pada tahun 2012, Angka Kematian Ibu (AKI) mencapai 359 per 100 ribu penduduk atau meningkat sekitar 57 persen bila dibandingkan dengan kondisi pada tahun 2007, yang hanya sebesar 228 per 100 ribu penduduk $^{4,5}$.

Data AKI di Provinsi Jawa Tengah tahun 2014 berdasarkan laporan kabupaten atau kota yaitu sebesar 126,55/100.000 kelahiran hidup, mengalami peningkatan bila dibandingkan dengan AKI pada tahun 2013 sebesar 118,62/100.000 kelahiran hidup, hal ini berarti terjadi peningkatan permasalahan kematian ibu di Provinsi Jawa Tengah ${ }^{5}$

Angka kematian ibu di Kabupaten Tegal pada tahun 2015 sebanyak 33 orang, 5 orang $(15,15 \%)$ meninggal pada masa hamil, 10 orang $(30,30 \%)$ meninggal pada saat persalinan dan 18 orang $(54,55 \%)$ meninggal pada masa nifas. Dapat diketahui kematian terbesar maternal terjadi pada waktu nifas yaitu 5 orang $(15,15 \%)$ meninggal disebabkan karena perdarahan, 3 orang $(9,09 \%)$ meninggal karena decomp cordis, 3 orang $(9,09 \%)$ meninggal karena eklamsi, 1 orang $(3,03 \%)$ meninggal karena PEB, 1 orang $(3,03 \%)$ meninggal karena B20/HIV, 2 orang $(6,06 \%)$ meninggi 1 sna jantung 1 orang $(3,03 \%)$ meninggal karena aspirasi, 2 orang $(6,06 \%)$ meninggal karena oedem paru ${ }^{6}$.

Asuhan masa nifas diperlukan dalam periode ini karena merupakan masa kritis baik ibu maupun bayinya9 ${ }^{9}$ Dengan demikian diperlukan suatu upaya untuk mencegah terjadinya tanda bahaya masa nifas. Untuk itu diperlukan peran serta dari tenaga kesehatan dengan memberikan konseling selama kehamilan, setelah persalinan dan melakukan kunjungan rumah yaitu KN 1 dan KN 2 sesuai standar pelayanan ${ }^{9,15}$. Penyebab tidak di ketahuinya masalah bahaya masa nifas yaitu kurangnya pengetahuan ibu nifas. Dimana faktor yang mempengaruhi pengetahuan dari ibu 
nifas yaitu (pendidikan, usia, pekerjaan, informasi, pengalaman, lingkungan, sosial ekonomi, sosial budaya) dan juga konseling dari tenaga kesehatan selama kehamilan dan setelah persalinan ${ }^{8,14}$.

Berdasarkan studi pendahuluan yang dilakukan pada bulan Januari 2017 di Puskesmas Pangkah, peneliti melakukan wasancara terbuka pada $10 \mathrm{ibu}$ nifas dengan hasil 2 orang ibu nifas berumur $<20$ tahun, $3 \mathrm{ibu}$ nifas berumur 21-25 tahun, 3 ibu nifas berumur 26-30 tahun dan 2 ibu nifas berumur 31-35 tahun dengan rata-rata kelahiran anak ke 2 dan ke 3. Saat di wawancarai tentang tanda bahaya masa nifas, 4 orang ibu mengaku sudah mengetahui dan paham tentang tanda bahaya masa nifas yang pernah dijelaskan oleh bidan dan 6 ibu lainnya mengaku belum mengetahui betul tanda bahaya masa nifas, mereka mengaku hanya dijelaskan singkat oleh dukun bayi. Di antara $10 \mathrm{ibu}$ nifas tersebut, 1 orang ibu dengan usia $<30$ tahun dan 3 orang ibu nifas usia $<25$ tahun mengeluh pernah mengalami pembengkakan, kemerahan yang disertai rasa sakit di area payudara (mastitis). Dimana 3 dari 4 ibu nifas tersebut langsung memeriksakan dirinya ke tenaga kesehatan setempat dan $1 \mathrm{ibu}$ lainnya hanya mengompres payudaranya dengan air hangat sesuai anjuran dukun bayi. Berdasarkan latar belakang tersebut peneliti tertarik untuk melakukan penelitian mengenai "Faktor-faktor yang Berhubungan dengan Pengetahuan Ibu Nifas tentang Tanda Bahaya Nifas di Puskesmas Pangkah Kabupaten Tegal”

\section{METODE PENELITIAN}

Desain penelitian ini adalah penelitian kuantitatif, dengan desain penelitian menggunakan metode cross sectional karena variabel independen dan variabel dependen diukur dalam waktu yang bersamaan atau simultan. Populasi dalam penelitian ini adalah ibu nifas di wilayah Puskesmas Pangkah. Teknik sampling pada penelitian ini menggunakan nonprobability sampling 12 . Sedangkan teknik pengambilan sampel yaitu purposive sampling. Data yang diambil dalam penelitian ini adalah data primer melalui kuesioner tertutup, data dianalisis menggunakan Uji chi square untuk melihat hubungan variable secara statistik bermakna atau tidak bermakna. Bermakna jika $\mathrm{H} 0$ ditolak ( $p$ value $\leq \alpha 0,05$ ) dan tidak bermakna jika $\mathrm{H} 0$ diterima ( $p$ value $>\alpha$ 0,05) dengan derajat kemaknaan (CI) $95 \%{ }^{12,17}$.

Analisis keeratan hubungan dengan melihat nilai spearman rho untuk melihat keeratan hubungan antara dua variable karena data kategorik dan berdistribusi tidak normal. Pengolahan data dan analisis data dengan program SPSS for windows versi $16.0^{3,17}$.

\section{HASIL PENELITIAN}

Analisis univariat dilakukan untuk mengetahui gambaran pengetahuan ibu nifa tentang tanda bahaya nifas di Puskesmas Pangkah serta faktor-faktor yang berhubungan antara lain faktor umur, pendidikan dan pekerjaan, faktor pengalaman melahirkan dan keterpaparan ibu nifas mengenai tanda bahaya dalam nifas 
1. Karakteristik responden ibu nifas

Tabel 1. Karakteristik Responden Ibu Nifas di Puskesmas Pangkah Kabupaten Tegal Tahun 2017

\begin{tabular}{|c|c|c|}
\hline Variabel & Kategori & $\begin{array}{c}\text { Frekuensi \& } \\
\text { Persentase }\end{array}$ \\
\hline Umur & $\begin{array}{ll}- & <20 \text { tahun } \\
- & 20-35 \\
& \text { tahun } \\
- & >35 \text { tahun }\end{array}$ & $\begin{array}{l}1(3,2 \%) \\
20(64,5 \%) \\
10(32,3 \%)\end{array}$ \\
\hline Pendidikan & $\begin{array}{ll}\text { - } & \text { SD } \\
\text { - } & \text { SMP } \\
\text { - } & \text { SMA } \\
\text { - } & \text { Perguruan } \\
& \text { Tinggi }\end{array}$ & $\begin{array}{l}10(32,3 \%) \\
14(45,2 \%) \\
6(19,4 \%) \\
1(3,2 \%)\end{array}$ \\
\hline Pekerjaan & $\begin{array}{l}\text { - } \begin{array}{l}\text { Ibu rumah } \\
\text { tangga } \\
\text { - }\end{array} \text { PNS/ } \\
\text { pegawai } \\
\text { Swasta }\end{array}$ & $\begin{array}{l}30(96,8 \%) \\
1(3,2 \%)\end{array}$ \\
\hline $\begin{array}{l}\text { Pengalaman } \\
\text { melahirkan }\end{array}$ & $\begin{array}{ll}\text { - } & \text { Satu kali } \\
\text { - } & \text { Dua kali } \\
\text { - } & \text { Lebih dari } \\
& \text { dua kali }\end{array}$ & $\begin{array}{l}7(22,6 \%) \\
14(45,2 \%) \\
10(32,2 \%)\end{array}$ \\
\hline $\begin{array}{l}\text { Keterpaparan } \\
\text { informasi }\end{array}$ & $\begin{array}{ll}\text { - } & \text { Tidak } \\
& \text { Pernah } \\
\text { - } & \text { Pernah }\end{array}$ & $16(51,6 \%)$ \\
\hline \multicolumn{3}{|c|}{$\begin{array}{l}\text { 2. Gambaran Pengetahuan Ibu Nifas mengena } \\
\text { Tanda Bahaya Nifas } \\
\text { Tabel 2. Distribusi Responden Berdasarka } \\
\text { Pengetahuan Ibu Nifas tentang Tand } \\
\text { Bahaya Nifas di Puskesmas Pangka } \\
\text { Kabupaten Tegal Tahun } 2017\end{array}$} \\
\hline Pengetahu & an Jumlah & $\begin{array}{c}\text { Persentase } \\
(\%)\end{array}$ \\
\hline $\begin{array}{c}\text { Baik } \\
\text { Cukup } \\
\text { Kurang } \\
\text { Total }\end{array}$ & $\begin{array}{c}20 \\
6 \\
5 \\
31\end{array}$ & $\begin{array}{l}64,5 \\
19,4 \\
16,1 \\
\mathbf{1 0 0}\end{array}$ \\
\hline
\end{tabular}

Analisis bivariat dilakukan untuk melihat ada tidaknya hubungan antara variabel dependen (pengetahuan ibu nifas mengenai tanda bahaya dalam masa nifas) dengan variabel independen yaitu faktor-faktor yang berhubungan antara lain umur, pendidikan dan pekerjaan, pengalaman melahirkan dan keterpaparan ibu nifas

Analisis statistik yang digunakan adalah dengan melakukan uji normalitas data metode shapiro wilk dan lilliefors, dengan hasil semua data variabel memiliki nilai pvalue $>0,05$ (distribusi normal), sehingga analisis bivariat yang digunakan yaitu statistik nonparametrik uji hubungan chi square dengan derajat kemaknaan (CI) $95 \%$ dan nilai $\alpha=0,05$. Apabila pvalue $\leq \alpha$ maka Ho ditolak yang artinya ada hubungan yang bermakna sedangkan pvalue $\geq \alpha$ maka Ho diterima yang artinya tidak ada hubungan yang bermakna. Sedangkan untuk menilai faktor yang paling kuat mempengaruhi, maka digunakan uji koefisien korelasi spearman rho.

3. Analisis Kekuatan Faktor yang Berhubungan dengan Pengetahuan Ibu Nifas tentang Tanda Bahaya Nifas di Puskesmas Pangkah Kabupaten Tegal Tahun 2017

Tabel 3. Analisis Kekuatan Faktor yang Berhubungan dengan Pengetahuan Ibu Nifas tentang Tanda Bahaya Nifas di Puskesmas Pangkah Kabupaten Tegal Tahun 2017

\begin{tabular}{llr}
\hline & & pengetahuan \\
\hline Umur & Pearson &, 417 \\
& Correlation & \\
& Sig. (2-tailed) &, 034 \\
& $\mathrm{~N}$ & 31 \\
& & pengetahuan \\
\hline Pendidikan & Pearson &, $734^{* *}$ \\
& Correlation &, 001 \\
& Sig. (2-tailed) & 31 \\
\hline
\end{tabular}




\begin{tabular}{llr}
\hline Pekerjaan & Pearson &, 158 \\
& Correlation & \\
& Sig. (2-tailed) &, 068 \\
& N & 31 \\
\hline Keterpaparan & Pearson &, $563^{*}$ \\
informasi & Correlation & \\
& Sig. (2-tailed) &, 040 \\
& N & 31 \\
\hline Pengalaman & Pearson &, $596^{* *}$ \\
melahirkan & Correlation &, 000 \\
& Sig. (2-tailed) & 31 \\
& N & 1 \\
\hline Pengetahuan & Pearson & \\
& Correlation & 31 \\
& Sig. (2-tailed) & N \\
& N & \\
\hline
\end{tabular}

Dari hasil penelitian tergambar diatas menunjukkan bahwa sejumlah $20(64,5 \%)$ ibu nifas memiliki pengetahuan yang baik. Responden ibu nifas mampu menjawab dengan benar pertanyaan yang tercantum dalam kuesioner yang meliputi perdarahan pervaginam, lochea yang berbau busuk, preeklamsia, sub-involusio, nyeri pada perut dan pelvis, pusing dan lemas yang berlebihan, suhu tubuh $>38^{\circ} \mathrm{C}$, kehilangan nafsu makan dalam waktu yang lama, trombhoplebitis, merasa sedih atau tidak mampu mengasuh diri sendiri dan bayinya, masalah laktasi dan demam, muntah, sakit saat berkemih. Hal tersebut mengindikasikan keberhasilan program kelas ibu di wilayah Puskesmas Pangkah, dimana salah satu materi penyuluhan yang diberikan bertemakan tentang tanda bahaya nifas ${ }^{2}$.

Tanda bahaya nifas yang paling banyak disebutkan oleh ibu nifas adalah perdarahan pervaginam $78,6 \%$, pusing dan lemas yang berlebihan $59 \%$, preeklampsia $44,7 \%$. Semakin tinggi pengetahuan seseorang maka akan semakin teratur dan abstrak cara berpikirnya. Pengetahuan merupakan domain dari suatu perilaku, sehingga seseorang tanpa pengetahuan tidak akan mempunyai dasar dalam mengambil keputusan dan menentukan tindakan yang harus dilakukan terhadap masalah tersebut ${ }^{1,7}$.

Pengetahuan yang baik pada ibu nifas tentang tanda bahaya nifas dapat menjadi pendukung keberhasilan program KIA di Puskesmas Pangkah dan akselerasi program penurunan AKI di Kabupaten Tegal pada umumnya.

Hasil analisis hubungan antara umur ibu nifas dengan pengetahuan ibu nifas tentang tanda bahaya nifas, diketahui pvalue $<\alpha$, artinya Ho ditolak, maka ada hubungan bermakna antara faktor umur dengan pengetahuan ibu nifas tentang tanda bahaya nifas. Hasil uji korelasi spearman rho menunjukkan nilai 0,417 yang artinya tingkat kekuatan hubungan sedang. Usia adalah umur individu yang terhitung mulai saat dilahirkan sampai saat berulang tahun, semakin cukup umur, tingkat kematangan seseorang akan makin kuat dalam berfikir dan bekerja. Semakin tua umur seseorang maka akan mempunyai kesempatan dan waktu yang lebih lama dalam mendapatkan informasi dan pengetahuan. Dengan demikian semakin tua umur responden maka pengetahuan ibu nifas tentang tanda bahaya masa nifas semakin baik ${ }^{7,13}$.

Tingkat pendidikan responden memiliki hubungan yang bermakna dengan pengetahuan 
ibu nifas tentang tanda bahaya nifas. Hasil analisis menunjukkan bahwa nilai pvalue $<\alpha$, artinya Ho ditolak, maka ada hubungan bermakna antara faktor pendidikan dengan pengetahuan ibu nifas tentang tanda bahaya nifas. Uji korelasi spearman rho menunjukkan nilai 0,734 yang artinya tingkat kekuatan hubungan tinggi. Makin tinggi pendidikan maka akan semakin mudah menerima informasi, sehingga semakin banyak pengetahuan yang diterimanya, tetapi sebaliknya semakin rendah tingkat pendidikan akan menghambat perkembangan sikap seseorang terhadap informasi dan hal-hal baru ${ }^{11}$.

Hal terserbut tidak sejalan dengan penelitian Meriana W (2016) dengan judul Hubungan Pendidikan dengan Pengetahuan Ibu Nifas tentang Tanda Bahaya Nifas di BPM Handayani Jepang Pakis Jati Kudus menunjukkan hasil bahwa pendidikan tidak ada hubungan dengan pengetahuan ibu. Pengetahuan ibu nifas diperoleh dari lingkungan pekerjaan, pengalaman, informasi dan kebudayaan lingkungan ${ }^{10}$.

Wanita yang berpendidikan akan lebih mudah untuk mendapatkan pelayanan profesional jika dibandingkan dengan wanita yang tidak berpendidikan karena wanita yang berpendidikan lebih menyadari manfaat dari pelayanan tersebut. Wanita yang berpendidikan akan lebih terbuka dan pantang menyerah untuk meningkatkan kemampuan menerima hal-hal baru ${ }^{7}$.
Hasil analisis berkaitan dengan faktor pekerjaan, diketahui tidak ada hubungan pekerjaan dengan pengetahuan ibu nifas tentang tanda bahaya nifas nilai pvalue $>\alpha$, artinya Ho diterima. Korelasi spearman rho menunjukkan nilai 0,158 yang artinya hampir tidak ada korelasi atau hubungan. Sebagian besar responden ibu nifas memiliki pekerjaan sebagai ibu rumah tangga 30 (96,8\%). Pendidikan membuat ibu nifas memperoleh pengetahuan, baik secara langsung maupun tidak langsung dari teman yang sudah lebih dahulu melahirkan. Hasil penelitian Nurleka Yulastri (2012) menunjukkan bahwa faktor pekerjaan tidak ada hubungan dnegan tingkat pengetahuan ibu hamil tentang masa nifas ${ }^{14}$.

Dari hasil analisis didapatkan adanya hubungan yang bermakna antara pengalaman melahirkan dengan pengetahuan ibu nifas tentang tanda bahaya nifas, dengan nilai pvalue $<\alpha$ dengan uji korelasi spearman rho menunjukkan nilai 0,596 yang artinya tingkat kekuatan hubungan sedang. Pengalaman hidup akan mempengaruhi minat dan motivasi seseorang untuk belajar, baik secara langsung maupun secara tidak langsung ${ }^{7}$.

Menurut Notoatmodjo (2010) pengalamanpengalaman seseorang mengawali terjadinya suatu perilaku. Pengalaman-pengalaman dipersepsikan, diyakini sehingga menimbulkan motivasi, niat untuk bertindak dan akhirnya terwujud suatu perilaku ${ }^{13}$.

Responden dalam penelitian ini rata-rata memiliki paritas dua kali, artinya telah 
mengalami persalinan sebanyak dua kali. Pengetahuan seseorang merupakan hasil dari pengalaman, yaitu dipengaruhi oleh pengalaman sebelumnya dan oleh kebutuhan individu. Pengalaman adalah suatu kejadian yang pernah dialami seseorang dari pengalaman akan membentuk sikap positif dalam kehidupannya 7,13 .

Hasil analisis berkaitan dengan faktor keterpaparan informasi, menunjukkan bahwa nilai pvalue $<\alpha$, artinya Ho ditolak, maka ada hubungan bermakna antara faktor keterpaparan informasi dengan pengetahuan ibu nifas tentang tanda bahaya nifas. Hasil uji spearman rho menunjukkan nilai 0,563 yang artinya tingkat kekuatan hubungan sedang.

Menurut Rogers dalam Notoatmodjo (2008), pengadopsi awal suatu inovasi ternyata lebih sering terpapar dengan informasi dibandingkan dengan pengadopsi lanjut. Kemudahan untuk mendapatkan informasi akan mempercepat individu untuk memperoleh pengetahuan yang baru ${ }^{13}$.

\section{SIMPULAN DAN SARAN}

Berdasarkan hasil analisis data pada penelitian ini, maka dapat disimpulkan sebagai berikut:

1. Gambaran Pengetahuan Ibu Nifas mengenai Tanda Bahaya Nifas

Hasil analisis menunjukkan sebagian besar $20(64,5 \%)$ ibu nifas memiliki pengetahuan baik, $6(19,4 \%)$ ibu nifas memiliki pengetahuan cukup dan $5(16,1 \%)$ ibu nifas memiliki pengetahuan kurang.

2. Gambaran Umur Ibu Nifas
Rerata umur responden ibu nifas yaitu umur 20-35tahun, umur termuda 18 tahun dan umur tertua 43 tahun. Hal tersebut menunjukkan hasil analisis bahwa sebagian besar responden berada pada rentang umur reproduksi sehat yaitu sejumlah $20(64,5 \%)$.

3. Gambaran Pendidikan Ibu Nifas

Pendidikan responden ibu nifas bervariasi, dimana paling banyak berpendidikan SMP 14 (45,2\%) dan hanya 1 $(3,2 \%)$ responden berpendidikan tinggi.

4. Gambaran Pekerjaan Ibu Nifas

Dari hasil analisis, sebagian besar responden ibu nifas memiliki pekerjaan sebagai ibu rumah tangga 30 (96,8\%) dan hanya $1(3,2 \%)$ yang bekerja sebagai karyawan swasta.

5. Gambaran Pengalaman melahirkan Ibu Nifas

Berdasarkan pengalaman melahirkan, sebanyak $14(45,2 \%)$ responden memiliki pengalaman melahirkan dua kali, $10(32,3 \%)$ responden memiliki pengalaman melahirkan lebih dari dua kali dan 7 (22,6\%) responden memiliki pengalaman melahirkan satu kali.

6. Gambaran Keterpaparan Informasi Ibu Nifas

Berdasarkan keterpaparan informasi, sebanyak $16(51,6 \%)$ responden tidak pernah mendapatkan informasi tentang tanda bahaya nifas, $15(48,4 \%)$ responden pernah mendapatkan informasi tentang tanda bahaya nifas.

7. Ada hubungan bermakna antara faktor umur dengan pengetahuan ibu nifas tentang tanda bahaya nifas.

BHAMADA, JITK, Vol. 10, No. 1, April 2019 
8. Ada hubungan bermakna antara faktor pendidikan dengan pengetahuan ibu nifas tentang tanda bahaya nifas.

9. Tidak ada hubungan bermakna antara faktor pekerjaan dengan pengetahuan ibu nifas tentang tanda bahaya nifas.

10. Ada hubungan bermakna antara faktor pengalaman melahirkan dengan pengetahuan ibu nifas tentang tanda bahaya nifas.

11. Ada hubungan bermakna antara faktor keterpaparan informasi dengan pengetahuan ibu nifas tentang tanda bahaya nifas.

12. Faktor pendidikan memiliki hubungan yang erat dengan pengetahuan ibu nifas, sedangkan faktor pengalaman melahirkan, keterpaparan informasi hubungan yang sedang dengan pengetahuan ibu nifas. Faktor pekerjaan hampir tidak berhubungan dengan pengetahuan ibu nifas.

Diharapkan hasil penelitian ini dilaksanakan penelitian lanjutan untuk melihat keterdalaman hubungan antar variabel dengan sampel penelitian yang lebih besar dan tempat penelitian yang berbeda. Perlunya pemberdayaan kader kesehatan dalam agar mampu memberikan penyuluhan tentang tanda bahaya nifas di posyandu. Perlunya peningkatkan pelaksanaan KIE pada saat KF1, KF2, KF3 kepada ibu nifas mengenai tanda bahaya pada masa nifas dan faktor resikonya. Dan ibu nifas diharapkan meningkatkan pengetahuan dalam perawatan masa nifas, meningkatkan kemampuan dalam melakukan deteksi dini tanda bahaya nifas dan faktor resikonya serta segera melakukan pemeriksaan ke tenaga kesehatan bila menemukan tanda bahaya sehingga tidak terlambat dalam penatalaksanaannya.

\section{DAFTAR PUSTAKA}

1. Abd. Rahman. Hubungan Pengetahuan dan Sikap Ibu Hamil dalam Mengenal Tanda Bahaya Kehamilan dan Persalinan di Puskesmas Managaisaki. Jurnal Kesehatan Tadulako Vol 1 No 2, Juli 2015 : 1-78. http://jurnal.untad.ac.id/jurnal/index.php/Hea lthyTadulako/article/view/5736

2. Anggraini, Y. (2010). Asuhan kebidanan masa nifas. Yogyakarta: Pustaka Rihama

3. Arikunto, S. (2010). Prosedur penelitian suatu pendekatan praktik. Jakarta: PT. Rineka Cipta

4. Badan Kependudukan dan Keluarga Berencana Nasional. 2012. Survei Demografi dan Kesehatan Indonesia .Jakarta :Kementerian Kesehatan

5. Dinas Kesehatan Provinsi Jawa Tengah. (2014). Profil Kesehatan Provinsi Jawa Tengah Tahun. Semarang

6. Dinas Kesehatan Kabupaten Tegal. (2015). Profil Kesehatan Kabupaten Tegal.

7. Fitriani, Sinta. 2011. Promosi Kesehatan. Yogyakarta: Graha Ilmu

8. Hasnah \& Triatnawati, Atik (2003). Penelusuran Kasus-kasus Kegawatdaruratan Obstetri Yang Berakibat Kematian Maternal di RSUD Jawa Tengah. Makara Kesehatan Vol. 7 No 2 Desember 2003. http://repository.ui.ac.id/dokumen/lihat/56.pd $\mathrm{f}$

9. Marmi. (2014). Asuhan kebidanan pada masa nifas "puerperium care". Yogyakarta: Pustaka Pelajar

10. Meriana Wahyu S, Kudarti, Reny Siswanti. Hubungan Pendidikan dengan Pengetahuan Ibu Nifas tentang Tanda Bahaya Nifas di BPM Handayani Jepang Pakis Jati Kudus. Jurnal Kebidanan dan Kesehatan Akbid Mardi Rahayu Kudus Vol. 5 No 1 Tahun 2016. 
http://akbidmr.ac.id/layanan/e-jurnal/jurnalvol-5-no-1/

11. Mubarak, Wahit I, dkk. 2009. Promosi Kesehatan: Sebuah Pengantar Proses Belajar Mengajar dalam Pendidikan. Yogyakarta: Graha Ilmu

12. Notoatmodjo, S. (2010). Metodologi penelitian kesehatan. Jakarta : Rineka Cipta.

13. Notoatmodjo, S. (2005). Promosi Kesehatan, teori dan aplikasi. Jakarta : Rineka Cipta.

14. Nurleka Yulastri, Suci Destriatania, Fatmalina Febri. Hubungan Karakteristik Sosiodemografi dan Pelayanan Antenatal dengan Pengetahuan Ibu Hamil tentang Masa Nifas di Puskesmas Simpang Timbangan. Jurnal Ilmu Kesehatan Masyarakat Universitas Sriwijaya Vo. 3 No $3 \quad$ Tahun 2012. http://ejournal.fkm.unsri.ac.id/index.php/jik $\mathrm{m} /$ article/view/117

15. Prawirohardjo, S. (2007). Buku panduan praktis pelayanan kesehatan maternal dan neonatal. Jakarta: YBPSP

16. Prawirohardjo, S. (2010). Ilmu kebidanan. Jakarta: PT Bina Pustaka

17. Sugiyono. (2010). Statistika penelitian. Bandung: Alfabeta 